\title{
ANALISIS PENGAJUAN SOAL MATEMATIKA SISWA SMP DITINJAU DARI GAYA KOGNITIFFAST ACCURATE DAN SLOW IN ACCURATE
}

\author{
Ana Rahmawati \\ Pendidikan Matematika,FPMIPA,Unipdu Jombang \\ e-mail: anarahmawati@mipa.unipdu.ac.id
}

\begin{abstract}
: this research is a descriptive research with qualitative approach as it is meant to describe question submission of Junior High School students seen from cognitive style, namely; fast-accurate style cognitive style and slow-inaccurate style. The data collection method used in this research are test and interview. The data credibility is then tested through triangulation of time. the result shows that the description of question submission submitted by subject of fastaccurate are; most of the questions submitted are mathematical questions except few of them are not, the questions submitted by the subject are varied, most of the questions submitted are from visual information, all questions submitted can be solved, the questions submitted by the fastaccurate subject are balance between medium and high difficulty, the solution of all questions submitted are correct. The submission of questions done by slow-inaccurate group are: most of the questions submitted by slow-inaccurate group are mathematical questions except one, the questions submitted are varied, the questions submitted from visual and verbal information are balance where 6 questions are from visual and the other 6 are from verbal, most of the questions can be solved except one, most of the questions are in medium level of difficulty, most of the questions can be solved correctly except question number 9 which can be solved as the information given are not enough to solve the problem.
\end{abstract}

Keywords:questions submission; fast-accurate cognitive style; slow-inaccurate cognitive style.

\begin{abstract}
Abstrak: Penelitian ini merupakan penelitian deskriptif dengan menggunakan pendekatan kualitatif karena bertujuan untuk mendeskripsikan pengajuan soal matematika siswa SMP ditinjau dari gaya kognitif, yaitu gaya kognitif fast-accurate dan gaya kognitif slow-inaccurate. Pengumpulan data pada penelitian ini dilakukan dengan metode tes dan metode wawancara. Selanjutnya untuk menguji kredibilitas data, dilakukan triangulasi waktu.Hasil penelitian ini menunjukkan bahwa deskripsi pengajuan soal yang diajukan oleh subjek fast-accurate adalah: ada beberapa soal yang diajukan merupakan soal non matematika tetapi pada umumnya soal yang diajukan subjek fast-accurate merupakan soal matematika, soal-soal matematika yang diajukan adalah beragam, pada umumnya soal-soal yang diajukan bersumber dari informasi visual; semua soal yang diajukan dapat terpecahkan, soal yang diajukan oleh subjek fast-accurate berimbang antara yangberada pada tingkat kesulitan sedang dan tinggi, semua soal yang diajukan penyelesainnya benar.Pengajuan soal yang diajukan oleh subjekslow-inaccurate adalah: ada sebuah soal yang diajukan merupakan soal non matematika tetapi pada umumnya soal yang diajukan subjek slow-inaccurate merupakan soal matematika, soal-soal matematika yang diajukan adalah beragam, soal-soal yang diajukan bersumber dari informasi visual dan verbal berimbang yaitu 6 soal dari informasi visual dan 6 soal dari informasi verbal; ada sebuah soal yang tidak dapat terpecahkantetapi pada umumnya soal yang diajukan dapat terpecahkan, pada umumnya soal yang diajukan berada pada tingkat kesulitan sedang, semua soal yang diajukan penyelesainnya benarkecuali soal nomor 9 yang tidak dapat diselesaikan karena informasinya belum cukup untuk menyelesaikan soal tersebut.
\end{abstract}

Kata kunci: Pengajuan Soal; Gaya KognitifFast-Accuarate; Gaya Kognitif Slowinaccurate 


\section{PENDAHULUAN}

Pendidikan adalah salah satu kebutuhan dan salah satu hal yang penting bagi kehidupan manusia karena dengan menempuh pendidikan orang akan memperoleh banyak pengetahuan. Terkait dengan pendidikan, kualitas pendidikan di Indonesia harus terus ditingkatkan karena melalui pendidikan yang berkualitas dapat menghasilkan generasi penerus bangsa yang kompeten dan cerdas dibidangnya.

Matematika merupakan salah satu pelajaran yang diajarkan kepada peserta didik mulai dari jenjang pendidikan dasar, pendidikan menengah dan di pendidikan tinggipun juga terdapat mata kuliah yang berhubungan dengan matematika.

Terkait dengan pendidikan, khususnya pelajaran matematika berdasarkan hasil survei Programme for International Student Assesment (PISA) tahun 2012 menempatkan Indonesia pada peringkat 64 dari 65 negara dengan skor rata-rata 375 (OECD, 2014). Sedangkan pada tahun 2015menempatkan peringkat Indonesia di posisi 64 dari 72 negara dengan skor ratarata 386 untuk pelajaran matematika (OECD, 2016). Berdasarkan hasil tersebut, Indonesia masih berada di posisi 10 besar dari bawah walaupun terdapat peningkatan skor rata-rata dari 375 pada tahun 2012 menjadi 386 pada tahun 2015.

Berdasarkan informasi tersebut, Indonesia harus terus berbenah untuk memperbaiki kualitas pendidikan.Dalam pendidikan formal, beberapa faktor sepertikurikulum, guru, sarana dan prasarana, dukungan dari sekolah maupun orang tua memberikan kontribusi yang sangat penting terhadap pencapaian prestasi belajar matematika siswa. Salah satu upaya/ cara yang dapat dilakukan untuk memperbaiki kualitas pendidikan di sekolah adalah dengan cara memperbaiki proses pembelajaran di kelas. Guru sebagai pendidik mempunyai peranan penting untuk membangun dan mengembangkan pengetahuan siswanya, salah satu upaya yang dapat dilakukan guru adalah dengan menerapkan pembelajaran menggunakan pengajuan soal.

Pengajuan soal/masalah dalam pembelajaran dapat diartikan sebagai meminta siswa untuk membuat soal/ masalah berdasarkan informasi yang telah diberikan.Berdasarkan NCTM (Lavy \& Shriki, 2007) pengajuan soal diakui sebagai komponen penting dari mengajar dan belajar matematika. Selanjutnya Cunningham (Lavy \& Shriki, 2007) menunjukkan bahwa dengan memberikan kesempatan pada siswa untuk mengajukan masalah dapat meningkatkan penalaran siswa dan refleksi siswa. Ketika siswa merumuskan masalah baru dapat menumbuhkan rasa kepemilikan bahwa siswa perlu untuk membangun pengetahuan mereka sendiri. Berdasarkan beberapa pendapat tersebut pengajuan soal ini perlu dilatihkan pada peserta didik agar dapat membangun pengetahuan pesera didik untuk berpikir matematis dan meningkatkan penalaran peserta didik.

Dalam melaksanakan proses pembelajaran guru juga harus memperhatikan karakteristik siswa, salah satunyanya yaitu gaya kognitif siswa karena gaya kognitif merupakan karakteristik dari setiap individu.Messick (Kozhevnikov, 2007) mendefinisikan gaya kognif sebagai sikap yang stabil, preferensi, atau strategi yang menentukan cara seseorang untuk mempersepsi, mengingat, berpikir dan memecahkan masalah. Sedangkan Kefee (Uno, 2008) mendefinisikangaya kognitif sebagai cara siswa yang khas dalam mempelajari sesuatu, baik yang terkait 
dengan cara penerimaan dan pengolahan suatu informasi, sikap terhadap suatu informasi, maupun yang terkait dengan kebiasaan yang berhubungan dengan lingkungan belajar.Setiap siswa mempunyai cara berbeda dalam merespon pembelajaran, jika dalam proses pembelajaran guru tidak memperhatikan gaya kognitif dari siswanya maka tentu proses pembelajaran tidak akan memperoleh hasil yang maksimal. Dalam mengajukan soal/ masalah akan ada informasi yang diterima oleh siswa, selanjutnya informasi tersebut diproses, disimpan dan digunakan untuk mengajukan masalah berdasarkan pada pengetahuan maupun pengalaman yang dimiliki oleh tiap-tiap siswa. Dengan demikian seorang siswa pada saat mengajukan soal salah satunya dipengaruhi oleh gaya kognitifnya.

Terkait dengan gaya kognitif, Rozencwajg dan Corroyer (2005) menyatakan bahwa gaya kognitif dapat dibagi menjadi 4 golongan yaitu a) gaya kognitif reflektif; b) gaya kognitif impulsif; c) gaya kognitif fast-accurate dan d) gaya kognitifslow-inaccurate. Dalam beberapa penelitian gaya kognitif reflektif dan gaya kognitif impulsif sudah banyak dikaji/diteliti, sehingga peneliti ingin mengkaji siswa yang bergaya kognitif fastaccurate dan siswa yang bergaya kognitif slow-inaccuarate.

\section{METODE}

Informasikan secara ringkas mengenai materi dan metode yang digunakan dalampenelitian, meliputi subyek/bahan yang diteliti, alat yang digunakan, rancangan percobaanataudesainyangdigunakan,teknikp engambilansampel,variabelyang akan diukur, teknik pengambilan data, analisis dan model statistik yang digunakan.
Penelitian ini adalah penelitian deskriptif denganmenggunakan pendekatan kualitatif.Penelitian ini bertujuan untuk mendeskripsikan pengajuan soal matematika dari subjek penelitian. Adapun subjek pada penelitian ini diambil dari siswa kelas IX MTS Ma'arif Pare. Siswa MTS Ma'arif Pare diberi tes gaya kognitif untuk memetakan siswa berdasarkan jenis gaya kognitif. Instrumen gaya kognitif yang digunakan diadopsi dari Warli (2010) yang telah teruji validitasnya maupun reliabilitasnya. Subjek pada penelitian ini adalah seorang siswa yang beradapada kelompok gaya kognitif fast-accurate dan seorang siswa yang berada pada kelompok gaya kognitif slow-inaccurate yang mana masing-masing siswa tersebutdipilih yang dapat mengomunikasikan pendapatnya baik secara tertulis maupun secara lisan. Subjek dengan gaya kognitif fast-accurate diberi simbol FAdan subjek dengan gaya kognitif slow-inaccurate disimbolkan dengan SA.

Untuk mendapatkan data yang dibutuhkan, subjek diberi tes untuk menyelesaikan tugas pengajuan soal (TPS). Setelah subjek menyelesaikan TPS langkah selanjutnya adalah melakukan wawancara berkaitan dengan hasil pekerjaan subjek atas TPS yang diberikan. Tujuan dari wawancara ini adalah untuk menggali data yang tidak dapat diidentifikasi dari jawaban tertulis subjek dan untuk mengonfirmasi jawaban tertulis subjek.Selanjutnya sebelum melakukan analisis, perlu diadakan triangulasi waktu yang mana bertujuan untuk memeriksa keabsahan data. Data yang sudah valid selanjutnya dianalisis dan kemudian disimpulkan. Dari simpulan tersebut akan diperoleh deskripsimengenai pengajuan soal subjek ditinjau dari gaya kognitif fast-accurate dan gaya kognitif slow-inaccurate. 
Kriteria yang digunakan untuk menganalisis pengajuan soal subjek diadopsi dari Muiz (2008) dan Siswono (1999), yaitu:

1. Keberagaman materi terkait dengan soal yang diajukan

a. Materinya dikatakan beragam jika soal yang diajukan memuat lebih dari empat konsep matematika yang berbeda.

b. Materinya dikatakan kurang beragam jika soal yang diajukan menggunakan dua atau tiga konsep matematika yang berbeda.

c. Materinya dikatakan tidak beragam jika soal yang diajukan menggunakan satu konsep matematika saja.

2. Kecenderungan dari informasi yang digunakan.Dalampenelitianini, informasipadatugaspengajuansoaltersajid alambentukinformasi verbal daninformasi visual. Siswacenderungdikatakanmenggunakani nformasi verbal apabiladalammengajukansoallebihbanya kmenggunakaninformasi verbal. Sebaliknya,

dikatakancenderungcenderungmemakaii nformasi visual apabiladalammengajukansoalmatematika lebihbanyakmenggunakaninformasi visual.

3. Dapat atau tidaknya soal diselesaikan/dipecahkan

Suatu soal dikatakan dapat diselesaikan/dipecahkan, jika memenuhi kriteria berikut: rumusan soal dinyatakan dengan tegas danjelas serta datayang diperlukan untuk menjawab soal tersebut dapat diperoleh dengan mengolah informasi yang diberikan. Jika kriteria tersebut tidak terpenuhi maka soal yang diajukan dikatakan tidak dapat diselesaikan/dipecahkan.

4. Tingkat kesulitan soal Dalam penelitian ini, tingkat kesulitan soal diklasifikasikan menjadi tiga kategori, yaitu:

a. Tingkat kesulitan soal rendah (mudah)

Apabila jawaban dari soal yang diajukan dapat diperoleh secara langsung dari informasi yang diberikantanpa adanya pengolahan data.

b. Tingkat kesulitan soal sedang Apabila jawaban dari soal yang diajukandapat diperoleh secara langsung dengan mengolah data yang sudah ada dari informasi yang diberikan atau jawaban dapat diperoleh langsung dengan satu kali pengolohan data.

c. Tingkat kesulitan soal tinggi (sulit) Apabila jawaban dari soal yang diajukan, tidak dapat diperoleh secara langsung dengan mengolah data yang sudah ada pada informasi. Artinya, dibutuhkan atau perlu dicari informasi baru sebelum menjawab soal yang diajukan, atau dibutuhkan minimal dua kali pengolohan data untuk memperoleh jawaban dari soal yang diajukan.

5. Jawaban atas soal yang dibuat

Penyeleseian dari soal yang dibuat oleh siswa dilihat, apakah penyelesaian tersebut benar ataukah salah.

\section{HASIL DAN PEMBAHASAN}

Pada penelitian ini, subjek diberikan tugas pengajuan soal 1 (TPS I) dan tugas pengajuan soal 2 (TPS II). Adapun tugas pengajuan soal yang diberikan kepada subjek telah divalidasi oleh dosen pendidikan matematika Unipdu. Selanjutnya tugas pengajuan soal matematika tersebut juga diujicobakan kepada seorang siswa kelas IX untuk mengetahui apakah informasi dan perintah pada TPS yang dibuat dapat dipahami atau tidak oleh siswa tersebut. Jika informasi dan perintah pada TPS tersebut tidak dapat dipahami oleh siswa, maka TPS tersebut harus direvisi 
kemudian diujicobakan lagi. Tetapi jika siswa dapat memahami informasi dan perintah pada TPS tersebut, berarti TPS tersebut sudah layak digunakan untuk subjek penelitian.

Setelah subjek diberi tugas waktu yang berbeda subjek diberi tugas pengajuan soal 2 (TPS 2) yang mana TPS 2 tersebut ekuivalen dengan TPS 1 yang bertujuan untuk mengecek keabsahan data.

Setelah subjek diberi tugas pengajuan soal 2 (TPS 2) dan diperoleh hasil jawaban tertulis, langkah selanjutnya yang dilakukan oleh peneliti adalah menelaah jawaban tertulis subjek dan kemudian mewawancarai subjekterkait pengajuan soal 1 (TPS 1) dan diperoleh hasil jawaban tertulis subjek, langkah selanjutnya yang dilakukan oleh peneliti adalah menelaah jawaban tertulis subjek dan kemudian mewawancarai subjek berdasarkan hasil jawaban tertulis.Pada berdasarkan hasil jawaban tertulis.

Setelah mendapat hasil jawaban tertulis dan hasil wawancara pada TPS I dan TPS II, langkah selanjutnya adalah membandingkan data yang diperoleh dari tes pertama dan tes kedua. Data yang diperoleh dari tes pertama dan kedua sudah sama, artinya data yang diperoleh dari tes pertama sudah valid, selanjutnya menganalisis data yang valid.

Berikut disajikan data pengajuan soal yang dibuat oleh subjek FA:

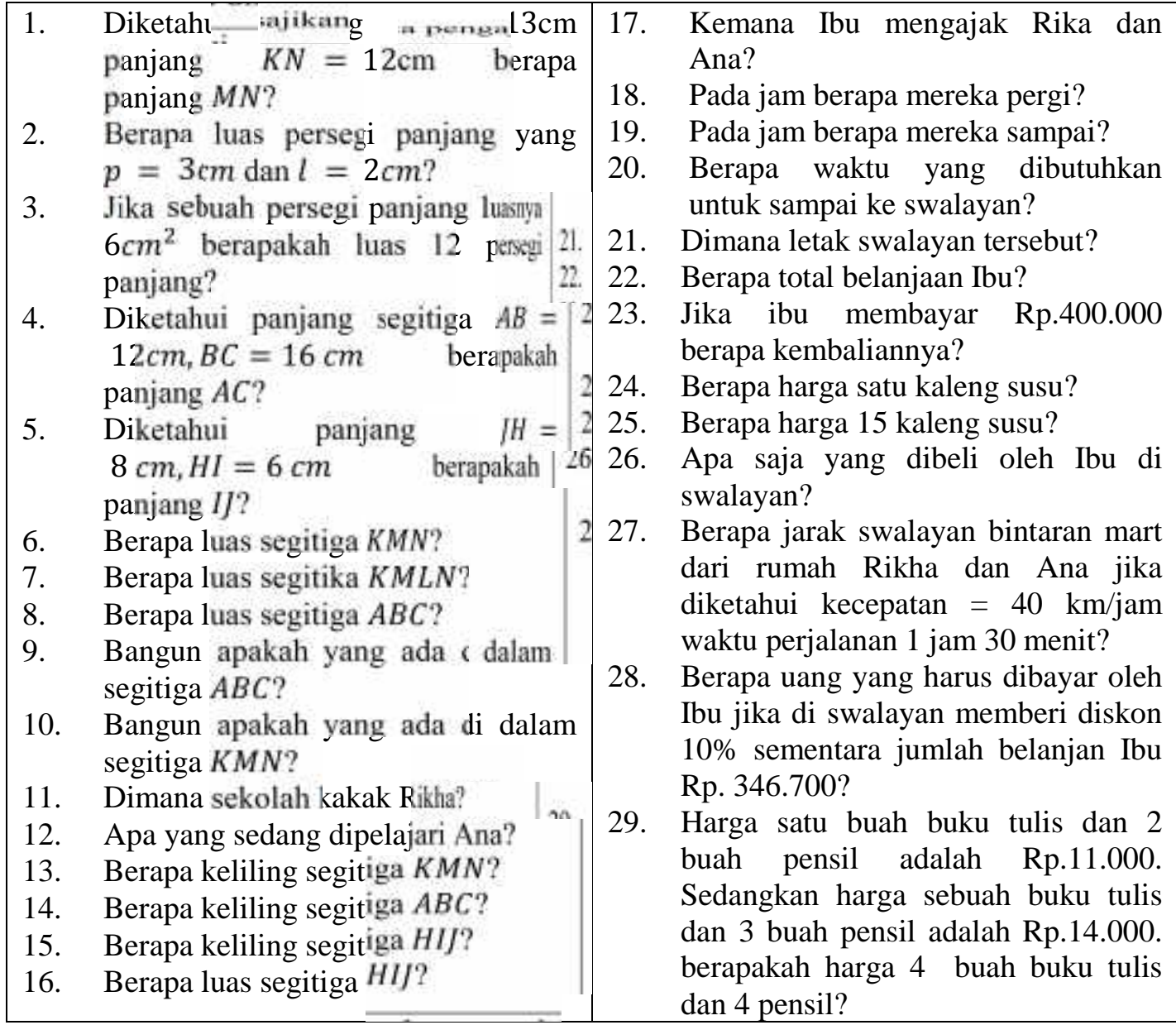

Catatan: pertanyaan-pertanyaan di atas adalahhasiltranskripdaripertanyaan-pertanyaan yang dituliskansiswa dan dari hasil wawancara.

Berdasarkan dari data pengajuan soal yang dibuat subjek fast-accurate (FA), FA 
membuat sebanyak 29 soal diantaranya adalah 25 soal merupakan soal matematika dan 4 soal merupakan soal non matematika. Berdasarkan dari hasil analisis, kriteria keberagaman materi subjek FA disajikan pada tabel 1 berikut:

Tabel 1.RekapitulasiPengajuanSoalMatematika SubjekFAberdasarkanpada KonsepMatematika

\begin{tabular}{lc}
\hline \multicolumn{1}{c}{ Konsep } & Banyaknya Soal \\
\hline Panjangsisibangundatar & 3 \\
\hline Luasbangundatar & 6 \\
\hline Kelilingbangundatar & 3 \\
\hline Jarak hitung & 1 \\
\hline $\begin{array}{l}\text { Operasi bilangan } \\
\text { (penjumlahan/pengurangan/ } \\
\text { pembagian) }\end{array}$ & 4 \\
\hline SistemPersamaan linier duavariabel & \\
\hline Diskon & 1 \\
\hline Himpunan & 1 \\
\hline Sifat bangun datar & 1 \\
\hline Perbandingan & 2 \\
\hline Waktu & 1 \\
\hline \multicolumn{1}{c}{ Jumlah Soal } & 2 \\
\hline
\end{tabular}

Berdasarkan pada tabel 1 di atas, dapat disimpulkan bahwa soal yang dibuat oleh subjek FA beragam karena menggunakan lebih dari empat konsep matematika yang berbeda.

Tabel 2.RekapitulasiPengajuanSoalMatematikaSubjek FABerdasarkanpada KecenderunganInformasi yang Digunakan

\begin{tabular}{|c|c|}
\hline Sumber & Banyaknya Soal \\
\hline Verbal & 11 \\
\hline Visual & 14 \\
\hline Jumlah Soal & 25 \\
\hline
\end{tabular}

Berdasarkan pada tabel 2 di atas, dapatdisimpulkanbahwasubjekFA cenderung membuat soal matematika yangberasaldariinformasi visual. Terlihat dari 25 soal yang telah dibuat oleh FA, FA membuat 14 soal yang bersumber dari informai visual, yaitu soal nomor 1, 2, 3, 4, $5,6,7,8,9,10,13,14,15$ dan soal nomor 16. Sedangkan soal yang lainnya berasal dari informasi visual.

Berdasarkan pada hasil analisis, kriteria soal yang diajukan oleh subjek FA apakah dapat diselesaikan atau tidak, disajikan pada tabel 3 berikut ini: 
Tabel 3.Rekapitulasi Pengajuan Soal Matematika SubjekFA Berdasarkan Soal yang Diajukan Dapat Diselesaikan atau Tidak Dapat Diselesaikan

\begin{tabular}{lc}
\multicolumn{1}{c}{ Soal } & Banyaknya Soal \\
\hline Soaldapatdipecahkan & 25 \\
\hline Soaltidakdapatdipecahkan & - \\
\hline Jumlah Soal & $\mathbf{2 5}$
\end{tabular}

Berdasarkan pada tabel 3 di atas, semua soal yang telah dibuat oleh subjek FA dapat diselesaikan dikarenakan rumusan soal yang telah dibuat oleh FA dinyatakan dengan jelas dan data-data yang dibutuhkan untuk menyelesaikan soal tersebut dapat diperoleh dengan mengolah informasi yang ada.

Berdasarkan pada hasil analisis, kriteria berdasarkan tingkat kesulitan soal yang diajukan oleh subjek FA, dapat disajikan pada tabel 4 berikut ini:

Tabel 4.Rekapitulasi Pengajuan Soal Matematika Subjek FA Berdasarkan pada Tingkat Kesulitan Soal

\begin{tabular}{lc}
\hline Soal & Banyaknya Soal \\
\hline Mudah (rendah) & 5 \\
\hline Sedang & 10 \\
\hline Sulit (tinggi) & 10 \\
\hline Jumlah Soal & $\mathbf{2 5}$ \\
\hline
\end{tabular}

Berdasarkan tabel 4 di atas, dapatdisimpulkanbahwa subjek FA membuat masing-masing membuat 10 soal pada tingkat kesulitan tinggi dan sedang. Soal-soal yang dibuat oleh subjek FAyang berada pada tingkatkesulitansedang, yaitu soal nomor 1, 2, 3, 4, 5, 8, 16, 20, 22, 24. Soal yang berada pada tingkat kesulitan sedang yaitu soal nomor $6,7,13,14,15$, 23, 25, 27, 28 dan soal nomor 29. Sedangkan soal nomor 9, 10, 18, 19 dan 26 berada pada tingkat kesulitan mudah.

Berdasarkan pada hasil analisis, kriteria apakah penyelesaian dari soal yang diajukan subjek oleh Subjek FA benar atau tidak disajikan pada tabel 5 berikut ini:

Tabel 5.Rekapitulasi Pengajuan Soal Matematika Subjek FA Berdasarkan Jawaban Atas Soal yang Dibuat

\begin{tabular}{lc}
\hline \multicolumn{1}{c}{ Soal } & Subjek A \\
\hline Benar & 25 \\
\hline Salah & - \\
\hline Jumlah Soal & $\mathbf{2 5}$ \\
\hline
\end{tabular}

Berdasarkan padatabel5 di atas, dapatdisimpulkanbahwasemuajawabansubj ekFA sudahbenar.

Selanjutnya, berikut ini adalah data pengajuan soal yang dibuat oleh subjek SA:

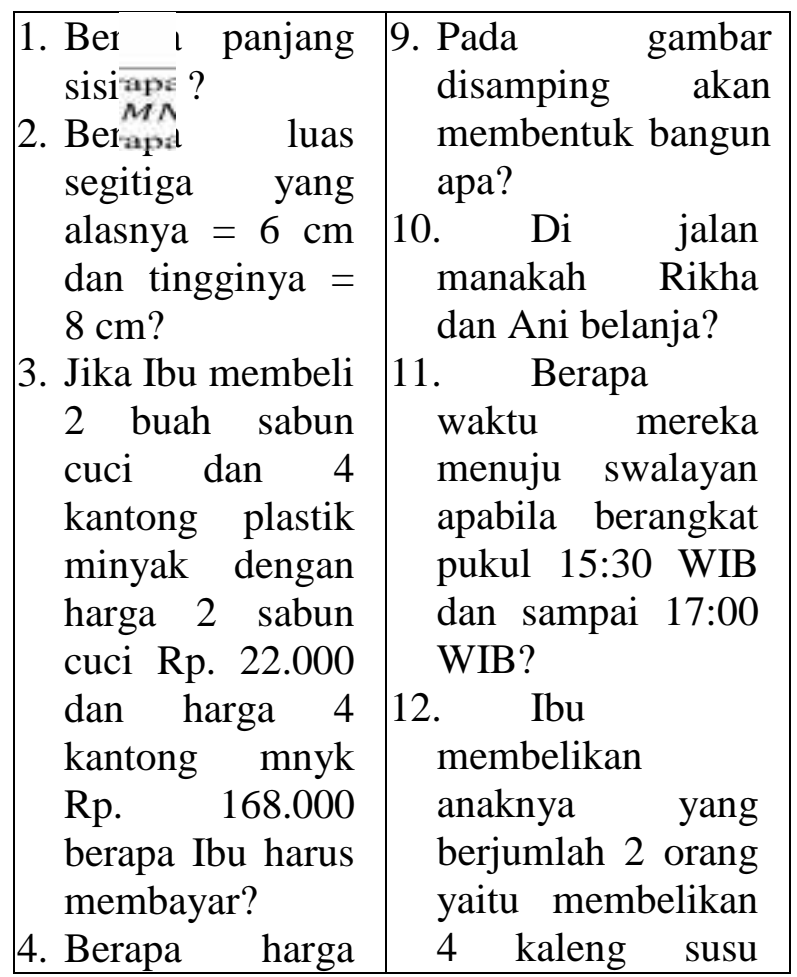




\begin{tabular}{|c|c|}
\hline 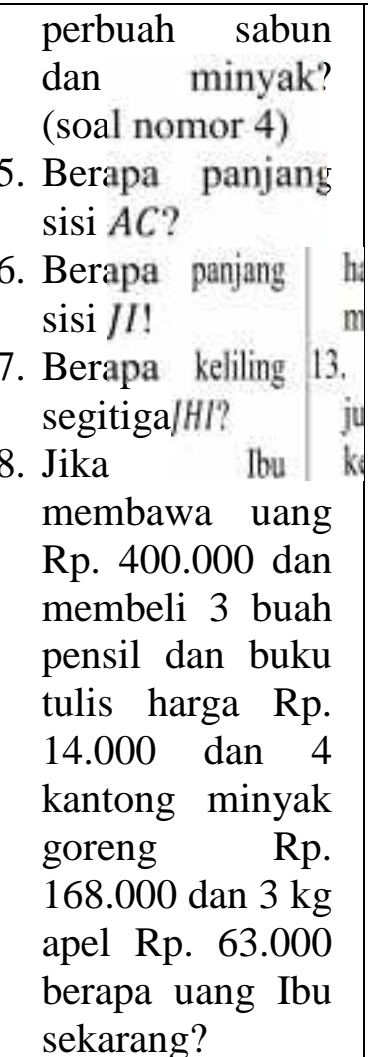 & $\begin{array}{l}\text { dengan harga Rp. } \\
34.000 \text { jika Ibu } \\
\text { hanya ingin } \\
\text { membeli } 2 \text { kaleng } \\
\text { susu berapakah Ibu } \\
\text { harus } \\
\text { membayarnya? } \\
\text { 13. Berapa } \\
\text { jumlah harga } \\
\text { keseluruhan yang } \\
\text { dibeli Ibu? }\end{array}$ \\
\hline
\end{tabular}

Catatan: Pertanyaan-pertanyaan di atas adalahhasiltranskripdaripertanyaan-

pertanyaan yang dituliskansiswa dan dari hasil wawancara.

Berdasarkan dari data pengajuan soal yang dibuat subjek slow-inaccurate (SA), SA membuat sebanyak13 soal diantaranya adalah 12 soal merupakan soal matematika dan 1 soal merupakan soal non matematika.Berdasarkan dari hasil analisis, kriteria keberagaman materi subjek SA disajikan pada tabel 6 berikut:

Tabel 6.

\begin{tabular}{lc}
\hline \multicolumn{1}{c}{ Konsep } & $\begin{array}{c}\text { Banyaknya } \\
\text { Soal }\end{array}$ \\
\hline Panjangsisibangundatar & 3 \\
\hline Luasbangundatar & 1 \\
\hline Kelilingbangundatar & 1 \\
\hline $\begin{array}{l}\text { Operasi hitung bilangan } \\
\text { (Penjumlahan/ } \\
\text { pengurangan/ } \\
\text { pembagian) }\end{array}$ & 4 \\
\hline Perbandingan & \\
\hline Waktu & 1 \\
\hline Sifat bangun datar & 1 \\
\hline \multicolumn{1}{c}{ Jumlah Soal } & $\mathbf{1 2}$ \\
\hline
\end{tabular}

Berdasarkan pada tabel 6 di atas, dapat disimpulkan bahwa soal yang dibuat oleh subjek SA beragam karena menggunakan lebih dari empat konsep matematika yang berbeda.

Berdasarkan hasil dari analisis, kriteria kecenderungan informasi yang digunakan oleh subjek SA dapat disajikan pada tabel 7 berikut ini:

Tabel7.RekapitulasiPengajuanSoalMatemat ikaSubjek

SABerdasarkanKecenderunganInformasi yang Digunakan

\begin{tabular}{lc}
\hline Sumber & Banyaknya Soal \\
\hline Verbal & 6 \\
\hline Visual & 6 \\
\hline Jumlah Soal & $\mathbf{1 2}$ \\
\hline
\end{tabular}

Berdasarkanpada tabel7 di atas, dapatdisimpulkanbahwasubjekSA cenderung membuat soal yangberasaldariinformasi visual dan visual berimbang. Terlihat dari 12 soal matematika yang telah dibuat oleh SA, SA membuat masing 6 soal yang bersumber dari informai visual dan 6 soal yang berasal dari informasi verbal. Soal nomor $1,2,5,6,7,9$ berasal dari informasi visula sedangkan soal nomor $3,4,8,11,12$ dan 13 berasal dari informasi verbal.

Berdasarkan pada hasil analisis, kriteria soal yang diajukan oleh subjek SA apakah dapat diselesaikan atau tidak, disajikan pada tabel 8 berikut ini:

Tabel 8.Rekapitulasi Pengajuan Soal Matematika SubjekSA Berdasarkan Soal yang Diajukan Dapat Diselesaikan atau Tidak Dapat Diselesaikan

\begin{tabular}{lc}
\hline \multicolumn{1}{c}{ Soal } & $\begin{array}{c}\text { Banyaknya } \\
\text { Soal }\end{array}$ \\
\hline Soaldapatdipecahkan & 11 \\
\hline Soaltidakdapatdipecahkan & 1 \\
\hline Jumlah Soal & $\mathbf{1 2}$ \\
\hline
\end{tabular}


Berdasarkan pada tabel 8 di atas, pada umumnya semua soal yang telah dibuat oleh subjek SA dapat diselesaikantetapi terdapat sebuah soal yang tidak dapat diselesaikan yaitu soal nomor 9, sebenarnya rumusan kata pada soal tersebut sudah jelas tetapi data yang diperlukan untuk menjawab soal tersebut tidak dapat diperoleh dengan mengolah informasi yang diberikan.

Berdasarkan pada hasil analisis, kriteria berdasarkan pada tingkat kesulitan soal yang diajukan oleh subjek SA, dapat disajikan pada tabel 9 berikut ini:

Tabel 9.Rekapitulasi Pengajuan Soal Matematika SA Berdasarkan TingkatKesulitan Soal

\begin{tabular}{lc}
\hline \multicolumn{1}{c}{ Soal } & Banyaknya Soal \\
\hline Mudah (rendah) & - \\
\hline Sedang & 6 \\
\hline Sulit (tinggi) & 5 \\
\hline Jumlah Soal & $\mathbf{1 1}$ \\
\hline
\end{tabular}

Berdasarkan padatabel9 di atas, dapatdisimpulkanbahwa subjek SA membuat membuat 5 soal pada tingkat kesulitan tinggi dan 6 soal pada tingkat kesulitan sedang. Soal-soal yang dibuat oleh subjek SAyang berada pada tingkatkesulitantinggi, yaitu soal nomor 3 , $4,7,8,12$. Soal yang berada pada tingkat kesulitan sedang yaitu soal nomor 1, 2, 5, 6, 11, 13. Sedangkan soal nomor 9 tidak dapat diidentifikasi tingkat kesulitannya karena tidak dapat diselesaikan.

Berdasarkan pada hasil analisis, kriteria apakah penyelesaian dari soal yang diajukan subjek oleh Subjek SA benar atau tidak disajikan pada tabel 10 berikut ini:
Tabel 10.Rekapitulasi Pengajuan Soal

Matematika SA Berdasarkan Jawaban Atas Soal yang Dibuat

\begin{tabular}{lc}
\hline \multicolumn{1}{c}{ Soal } & Subjek A \\
\hline Benar & 11 \\
\hline Salah & - \\
\hline Jumlah Soal & $\mathbf{1 1}$ \\
\hline
\end{tabular}

\section{SIMPULAN}

Deskripsi pengajuan soal yang diajukan oleh subjek fast-accurate adalah sebagai berikut:

1. Dari semua soal yang diajukan oleh subjek fast-accurate ada 4 soal yang diajukan merupakan soal non matematika tetapi pada umumnya soal yang diajukan subjek fast-accurate merupakan soal matematika;

2. Soal-soal matematika yang diajukan oleh subjek fast-accurate adalah beragam, yakni menggunakan 11konsep matematika;

a. Pada umumnya soal-soal yang diajukan oleh subjek fastaccuratebersumber dari informasi visual, yaitu sebanyak 14 soal dan soal yang menggunakan informasi verbal sebanyak 11 soal;

b. Semua soal yang diajukan oleh subjek fast-accuratedapat terpecahkan/ dapat diselesaikan,

c. Soal yang diajukan oleh subjek fastaccurate berimbang antara tingkat kesulitan sedang dan tingkat kesulitan tinggi, yakni 10 soal termasuk dalam kategori soal dengan tingkat kesulitan tinggi dan 10 soal termasuk pada soal dengan kategori tingkat kesulitan sedang;

d. Semua soal yang diajukan oleh subjek fast-accurate penyelesainnya benar. 
Deskripsi pengajuan soal yang diajukan oleh subjek slow-inaccurate adalah sebagai berikut:

a. Dari semua soal yang diajukan oleh subjek slow-inaccurate ada sebuah soal yang diajukan merupakan soal non matematika tetapi pada umumnya soal yang diajukan subjek slow-inaccurate merupakan soal matematika;

b. Soal-soal matematika yang diajukan oleh subjek slow-inaccurate adalah beragam, yakni menggunakan 7 konsep matematika;

c. Soal-soal yang diajukan oleh subjek slow-inaccuratebersumber dari informasi visual dan verbal berimbang yaitu 6 soal dari informasi visual dan 6 soal dari informasi verbal;

d. Ada sebuah soal yang dibuat oleh subjek slow-inaccuratetidak dapat terpecahkantetapi pada umumnya soal yang diajukan dapat terpecahkan;

e. Pada umumnya soal yang diajukan berada pada tingkat kesulitan sedang, yakni sebanyak 6 soal termasuk soal dengan tingkat kesulitan sedang;

f. Semua soal yang diajukan oleh subjekslow-inaccuratepenyelesaiannya benar, kecuali soal nomor 9 yang tidak dapat diselesaikan karena informasinya belum cukup untuk menyelesaikan soal tersebut.

Saran

a. Dari hasilpenelitian ini dapatdiketahuibahwapengajuansoal antarasubjekfastaccuratedansubjekslow-inaccurate berbeda.

Dapatdikatakanbahwapengajuansoalsub jekfast-

accuratecenderunglebihbaikdaripadasub jekslow-inaccurate. Olehkarenaitu, penelitimenyarankankepadapendidikpad a saat mengelolapembelajaranagar memperhatikanperbedaangayakognitif siswanya,

khususnyaketikamelatihpengajuansoalm atematikasiswa.

b. Penelitianinihanya sebatasmeneliti terkaitpengajuansoalmatematikasiswa ditinjaudarigayakognitiffast-

accuaratedanslow-inaccurate. Peneliti menyarankan untukpenelitianselanjutnya, agarmelakukanpenelitianyang sejenisdenganmemperhatikanperbedaanjeniskelaminsiswa.

c. Berdasarkan hasil penelitian ini, jika dilihat dari penyelesaian dari soal yang diajukan oleh subjek slow-inaccurate, subjek ini dapat menyelesaikan dengan tepat semua pertanyaan yang telah dia buat, kecuali pada pertanyaan nomor 9 subjek menjawab kurang tepat maka perlu diadakan penelitian lanjutan terkait kemampuan subjek slowinaccurate dalam menyelesaikan soal.

\section{DAFTAR PUSTAKA}

Kozhevnikov, Maria. 2007. Cognitive Style in the Context of Modern Psychology: Toward an Integrated Framework of Cognitive Style. Psychological Bulletin, (Online), Vol. 133(3).http://citeseerx.ist.psu.edu/vie wdoc/download;jsessionid $=1823 \mathrm{A0B}$ 0E7A5BD7ED5F331ADCC92953D? doi=10.1.1.600.5434\&rep=rep1\&type =pdf), diakses tanggal 5 Juni 2016.

Lavy, I., \& Atara, S. 2007. Problem Posing as a Means for Developing Mathematical Knowledge of Prospective Teachers. Proceeding of 
the $31^{\text {st }}$ Conference of the International Group for the Psychology of Mathematics Education, (Online), Vol. 3. (www.emis.de/proceedings/PME31/ 3/129.pdf), diakses tanggal 15 Juni 2016.

OECD. 2014. PISA 2012 Result in Focus: What 15-Year-Olds Know and What They Can DO With What They Know.

https://www.oecd.org/pisa/keyfinding s/pisa-2012-results-overview.pdf, diakses tanggal 30Mei 2016.

OECD. 2016. PISA 2015 Result in Focus. https://www.oecd.org/pisa/pisa-2015results-in-focus.pdf, diakses tanggal 26Desember 2016.

Muiz.

2008.

ProfilPengajuanMasalahSiswaBerda sarkanKemampuan Matematika dan Gender. Tesistidakditerbitkan. Surabaya:

ProgramPascasarjanaUnesa.

Rozencwajg\&Corroyer. 2005. Cognitive

Processes in the Reflective-Impulsive Cognitive Style. The Journal of Genetic Psychology, 166(4), (Online), (http://psycognitive.uparis10.fr/membres/rozencwajgcorroyer2005.pdf), diakses tanggal 18 Mei 2015.

Siswono, Tatag Yuli Eko. 1999. MetodePembelajaran Tugas Pengajuan Soal (Problem Posing) dalam Pembelajaran Matematika Pokok Bahasan Perbandingan di MTs Negeri Rungkut Surabaya. Tesis yang Tidak Dipublikasikan. Surabaya: Unesa University Press.
Uno, Hamzah B. 2008. Orientasi Baru dalam Psikologi Pembelajaran. Jakarta: Bumi Aksara.

Warli. 2010. Profil Kreativitas Siswa yang Bergaya Kognitif Reflektif dan Siswa yang Bergaya Kognitif Impulsif dan Reflektif dalam Memecahkan Masalah Geometri. Disertasitidakditerbitkan. Surabaya: Program PascasarjanaUnesa 
100 Jurnal Ilmiah Pendidikan Matematika, Vol. 5 No. 2, Maret 2017 hlm 89-99 